\title{
Serum Carcinoembryonic Antigen Levels and the Risk of Whole-body Metastatic Potential in Advanced Non- small Cell Lung Cancer
}

\author{
Dong Soo Lee1,6, Seung Joon Kim², Jin Hyoung Kang33, Sook Hee Hong3, Eun Kyoung Jeon³, Young Kyoon \\ $\mathrm{Kim}^{2}$, Ie Ryoung Yoo ${ }^{4}$, Jae Gil Park ${ }^{5}$, Hong Seok Jang, ${ }^{6}$ Hyo Chun Lee ${ }^{6}$ and Yeon Sil Kim ${ }^{6}$ \\ 1. Department of Radiation Oncology, Uijeongbu St. Mary's Hospital, College of Medicine, The Catholic University of Korea, Uijeongbu-si, \\ Gyeonggi-do, South Korea; \\ 2. Department of Internal Medicine, Seoul St. Mary's Hospital, College of Medicine, The Catholic University of Korea, Seoul, South Korea; \\ 3. Department of Medical Oncology, Seoul St. Mary's Hospital, College of Medicine, The Catholic University of Korea, Seoul, South Korea; \\ 4. Department of Nuclear Medicine, Seoul St. Mary's Hospital, College of Medicine, The Catholic University of Korea, Seoul, South Korea; \\ 5. Department of Thoracic Surgery, Seoul St. Mary's Hospital, College of Medicine, The Catholic University of Korea, Seoul, South Korea: \\ 6. Department of Radiation Oncology, Seoul St. Mary's Hospital, College of Medicine, The Catholic University of Korea, Seoul, South Korea.
}

$\triangle$ Corresponding author: Yeon Sil Kim, M.D., Ph.D. Department of Radiation Oncology, Seoul St. Mary's Hospital, College of Medicine, The Catholic University of Korea, 505 Banpo-dong, Seocho-gu, Seoul 137-701, South Korea. Tel.: +82 22258 6259; fax: +82 22258 1532. Email: yeonkim7@catholic.ac.kr.

(c) Ivyspring International Publisher. This is an open-access article distributed under the terms of the Creative Commons License (http://creativecommons.org/ licenses/by-nc-nd/3.0/). Reproduction is permitted for personal, noncommercial use, provided that the article is in whole, unmodified, and properly cited.

Received: 2014.06.II; Accepted: 2014.07.18; Published: 2014.09.05

\begin{abstract}
Background: This study aimed to clarify the clinical associations between serum carcinoembryonic antigen (CEA) levels and whole-body metastatic distribution in stage IV NSCLC patients.

Methods: This study analyzed 377 eligible patients between June 2007 and December 2012. All patients enrolled in the study were newly diagnosed with stage IV NSCLC and had records of pre-treatment serum CEA levels. The serum CEA levels were categorized as normal $(<5 \mathrm{ng} / \mathrm{ml})$ or abnormal ( $\geq 5 \mathrm{ng} / \mathrm{ml}$ ) to reveal clinically correlated factors with abnormal serum CEA levels.

Results: The median age of the study cohort was 65 years old (range, 30-94), and 236 (62.6\%) patients were male. Two hundred seventy-seven (73.5\%) patients had tumors with a histology that is consistent with adenocarcinoma. The median serum CEA value was $8.2 \mathrm{ng} / \mathrm{ml}$ (range, 0.I-2872.7), and 218 (57.8\%) patients had abnormal serum CEA levels. In multivariate analysis, abnormal serum CEA levels had statistically strong associations with non-squamous cell histology $(P=0.002)$, bone $(P=0.00 \mathrm{I})$, and brain metastases $(P=0.005)$; and were also closely correlated with positive metastatic $L N$ status $(P=0.083)$ and pulmonary metastasis $(P=0.065)$. Very high serum CEA levels $(\geq 100 \mathrm{ng} / \mathrm{ml})$ were additionally correlated with abdominal/pelvic metastasis $(P<$ 0.001 ).

Conclusions: Our findings suggested that abnormal serum CEA levels were strongly correlated with increased whole-body metastatic potential in advanced NSCLC. The results provided evidence for future exploratory anti-CEA targeting and intensive systemic assessment in advanced NSCLC patients with abnormal serum CEA levels.
\end{abstract}

Key words: Carcinoembryonic antigen; Immunotherapy; Non-small cell lung cancer; Metastases; Tumor marker.

\section{Introduction}

The epidemiology of lung cancer has been continuously evolving. According to a recent statistical study of cancer prediction in South Korean patients
[1], the estimated new and fatal cases of lung cancer in 2013 were 23,543 and 16,448, respectively, in South Korea. Although the incidence of lung cancer has 
been increasing in men and decreasing in women, it continues to constitute the first leading cause of cancer deaths in both groups [2]. With the change of lung cancer epidemiology, the clinical importance of non-squamous cell histology arising in relatively young-aged, never-smoking women has been steadily increasing [3, 4]. Although the vast majority (approximately two thirds) of lung cancer cases are found in locally advanced or advanced types, the unique metastatic patterns or underlying pathogenic mechanisms of cancer progression have not been definitely elucidated.

Serum carcinoembryonic antigen (CEA) is an established and long-term tumor marker, which has demonstrated its prognostic value in colorectal neoplasms $[5,6]$. CEA is overexpressed in approximately $70 \%$ of cases of non-small cell lung cancer (NSCLC), as well as more than $95 \%$ of adenocarcinomas of gastrointestinal origin [7]. The clinical usefulness of serum CEA in lung cancer has also been vigorously explored recently [8-12]. Although the preceding studies investigated the role of serum CEA for diagnostic or therapeutic purposes, its prognostic relevance within a heterogeneous lung cancer group has not yet been established. We previously identified that high serum CEA levels were significantly associated with brain metastasis detection at the time of diagnosis of stage IV NSCLC [13]. In the present study, we additionally aimed to clarify the relationship between whole-body metastatic features and serum CEA levels in a larger study cohort.

\section{Materials and Methods}

\section{Study eligibility and methods}

In this study, we analyzed the medical records of treatment-naïve stage IV NSCLC patients who were registered in a database at Seoul St. Mary's Hospital between June 2007 and December 2012. The eligibility criteria for study enrollment were as follows: patients who had information on serum CEA before any treatment; patients who were newly diagnosed with stage IV NSCLC by pathology; and patients who had available whole-body metabolic imaging, including 18F-fluorodeoxyglucose positron emission tomography/computed tomography (18F-FDG-PET/CT) and brain imaging. Patients with no available pathological confirmation or pretreatment whole-body imaging studies and patients with no systemic metastatic diseases in the staging work-up were excluded from this study. Among 549 stage IV NSCLC patients detected during the enrollment period, 377 patients met the inclusion criteria and were eligible for inclusion in this study. We obtained approval from the Institutional Review Board of the Catholic Medical Center
Ethics Committee at Seoul St. Mary's Hospital for this retrospective study.

Whole-body metastatic extent was categorized based on metabolic imaging, using 18F-FDG-PET/CT, $\mathrm{CT}$ of the whole chest and abdomen and magnetic resonance imaging (MRI) or CT of the brain. For the detection of central nervous system metastasis, MRI of the brain was preferentially conducted. Tc-99 m whole-body bone scans or MRI of the spine was selectively performed to determine the area of skeletal metastasis accurately. Cytologic examination for pleural or pericardial effusion was examined when clinically indicated. The distinction of reactive inflammatory changes from metastasis was sometimes challenging. Thus, imaging interpretation reports, performed by experienced nuclear medicine physicians and radiologists, or serial metabolic changes in corresponding regions were reviewed for accurate determination of the extent of metastasis.

In our previous study [13], we developed a whole-body metastatic score (WBMS) to categorize metastatic tumor spread, based on each metastatic site. Synchronous metastatic sites were classified into seven areas as follows: abdomen/pelvis (including liver, adrenal gland, lymph nodes, and other abdomino-pelvic organs); lung to lung or pulmonary lymphangitic spread; bone (skeletal system); pleura and/or pleural effusion and/or pericardial effusion; upper neck and/or axillary lymph nodes; other soft tissue; and the brain. Total scores were computed from 1 to 7 by the summation of each score. In this study, we additionally assessed the metastatic thoracic lymph node (LN) status to apply the metastatic $\mathrm{LN}$ extent. Metastatic LN status was defined as $\mathrm{CN} 0$ or $\mathrm{cN}+$ according to the clinical LN status, based on 18F-FDG-PET/CT. cN+ was defined as any metabolically positive $\mathrm{LN}$ state in the $\mathrm{cN} 0, \mathrm{cN} 1, \mathrm{cN} 2$ or $\mathrm{cN} 3$ stations. We calculated both WBMS and LN status-adjusted WBMS based on the aforementioned criteria, to estimate metastatic potential and tumor extent. LN-adjusted WBMS was calculated as the sum of WBMS and metastatic LN status.

\section{Measurement of serum CEA}

Blood samples were collected to measure serum tumor marker levels before the application of systemic treatment. The serum CEA level was measured using the enzyme immunoassay method, with an ADVIA Centaur ${ }^{\circledR}$ XP analyzer (Siemens, Munich, Germany). According to the manufacturer's instructions, the diagnostic cut-off point for serum CEA was $5.0 \mathrm{ng} / \mathrm{ml}$. With regard to the serum CEA level, values greater than $1,000 \mathrm{ng} / \mathrm{ml}$ were recorded before 2011 as $>1,000 \mathrm{ng} / \mathrm{ml}$ without any further dilution process. After 2011, serum CEA level was recorded as 
the highest estimated value measured by the maximal dilution process.

\section{Statistical analyses}

Statistical analyses were conducted using SPSS software (ver. 17.0; SPSS Inc., Chicago, IL, USA). Descriptive statistics were generated to present the characteristics of the variables. Pearson's chi-square test or Fisher's exact test was performed to assess the differences between groups for categorical variables. Nonparametric tests, such as Wilcoxon's rank-sum test or the Kruskal-Wallis test, were used for continuous variable (serum CEA), if the distribution of serum CEA was non-standard. Univariate and multivariate logistic regression analyses were applied to select significant factors associated with increased serum CEA levels. All of the statistical results were two-sided and were considered statistically significant if $\mathrm{P}<0.05$.

\section{Results}

\section{Patient and tumor characteristics}

The patient and tumor characteristics are summarized in Table 1 . The median age was 65 years old (range, 30-94), and 62.6\% were male. Because serum CEA levels were preferentially examined in non-squamous cell carcinoma, the majority of the patients had histology consistent with adenocarcinoma $(73.5 \%)$. The median serum CEA value was $8.2 \mathrm{ng} / \mathrm{ml}$ (range, $0.1-2872.7$ ), and $42.2 \%$ of the patients presented within the normal range for serum CEA $(<5$ $\mathrm{ng} / \mathrm{ml})$. A histogram that describes the distribution of CEA levels in the entire cohort is shown in Figure 1.

Table I. Patient demographics and tumor characteristics $(N=$ 377).

\begin{tabular}{lll}
\hline Characteristics & & No. of patients (\%) \\
\hline Age & & \\
Median (range) & $65(30-94)$ & \\
& $<65$ & $176(46.7)$ \\
& $\geq 65$ & $201(53.3)$ \\
Gender & Male & $236(62.6)$ \\
Histology & Female & $141(37.4)$ \\
& Adenocarcinoma & $277(73.5)$ \\
& Squamous cell carcinoma & $62(16.4)$ \\
Tumor differentiation & Large cell carcinoma & $16(4.2)$ \\
& Others & $22(5.8)$ \\
& MD & $32(8.5)$ \\
& PD & $152(40.3)$ \\
CEA levels & Unknown & $124(32.9)$ \\
Median (range) & $8.2(0.1-2872.7)$ & $69(18.3)$ \\
& $<5$ ng/ml & \\
Smoking status & $\geq 5$ ng/ml & $159(42.2)$ \\
& Never smoker & $218(57.8)$ \\
& Ever (Current+Former) smoker & $211(56.0)$ \\
& Unknown & $12(3.2)$ \\
\hline
\end{tabular}

Abbreviations: WD, well differentiated; MD, moderate differentiated; PD, poorly differentiated; CEA, carcinoembryonic antigen.

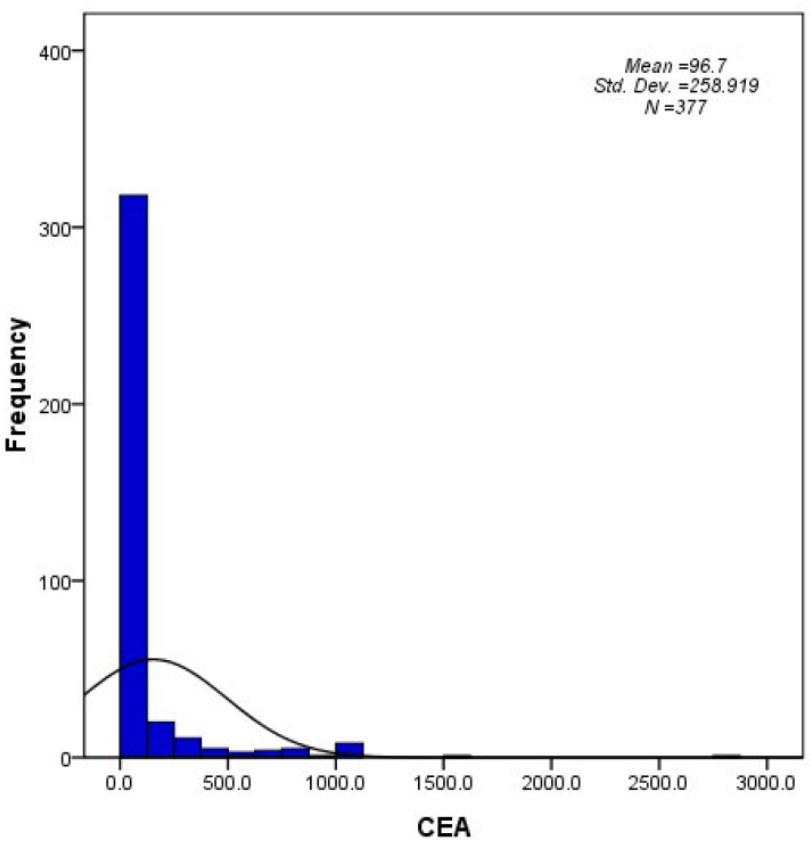

Figure I. A histogram describing the distribution of CEA levels in the study population $(\mathrm{N}=377)$.

\section{Whole-body metastatic characteristics in the entire population}

Whole-body metastatic characteristics are summarized in Table 2. Sixty (15.9\%) patients showed a cN0 metastatic LN status. Among 317 (84.1\%) LN+ patients, $28(7.4 \%), 129(34.2 \%)$ and $160(42.4 \%)$ patients showed cN1, cN2 and cN3 status, respectively. Bone and lung to lung/lymphangitic spread were the most common metastatic distributions $(56.5 \%$ and $59.7 \%$, respectively). Brain metastasis was detected in $113(30 \%)$ patients.

\section{Patient and metastatic characteristics according to the serum CEA}

Table 3 shows the patient and metastatic characteristics according to serum CEA levels. When categorized according to normal and abnormal serum CEA levels, abnormal serum CEA was more commonly detected in female patients $(P=0.013)$, patients with non-squamous cell histology $(\mathrm{P}<0.001)$, patients with $\mathrm{cN}+(\mathrm{P}=0.002)$, patient with lung to lung metastasis/lymphangitic spread $(\mathrm{P}=0.003)$, patients with bone metastasis $(\mathrm{P}<0.001)$ and patients with brain metastasis $(P<0.001)$. Among the total of 213 bone and 113 brain metastasis patients, 150 (70.4\%) and $82(72.6 \%)$ patients exhibited abnormal serum CEA levels, respectively. Similarly, among the total of $317 \mathrm{cN}+$ and 225 lung to lung/lymphangitic metastasis patients, $194(61.2 \%)$ and $144(64 \%)$ patients exhibited abnormal serum CEA levels, respectively. 
Table 2. Whole-body metastatic characteristics of the cohort $(\mathrm{N}=377)$

\begin{tabular}{|c|c|c|}
\hline Characteristics & & No. of patients (\%) \\
\hline \multicolumn{3}{|l|}{ Whole-body metastatic score } \\
\hline \multirow[t]{7}{*}{ Median (range) } & $2(1-6)$ & \\
\hline & 1 & $104(27.6)$ \\
\hline & 2 & $111(29.4)$ \\
\hline & 3 & $94(24.9)$ \\
\hline & 4 & $48(12.7)$ \\
\hline & 5 & $18(4.8)$ \\
\hline & 6 & $2(0.5)$ \\
\hline \multicolumn{3}{|c|}{ LN-adjusted whole-body metastatic score } \\
\hline \multirow[t]{8}{*}{ Median (range) } & $3(1-7)$ & \\
\hline & 1 & $37(9.8)$ \\
\hline & 2 & $81(21.5)$ \\
\hline & 3 & $103(27.3)$ \\
\hline & 4 & $90(23.9)$ \\
\hline & 5 & $48(12.7)$ \\
\hline & 6 & $16(4.2)$ \\
\hline & 7 & $2(0.5)$ \\
\hline \multirow[t]{2}{*}{ Bone } & No & $164(43.5)$ \\
\hline & Yes & $213(56.5)$ \\
\hline \multirow[t]{2}{*}{ Lung/Lymphangitic spread } & No & $152(40.3)$ \\
\hline & Yes & $225(59.7)$ \\
\hline \multirow[t]{2}{*}{ Pleura/Effusions } & No & $197(52.3)$ \\
\hline & Yes & $180(47.7)$ \\
\hline \multirow[t]{2}{*}{ Abdomen/Pelvis } & No & $253(67.1)$ \\
\hline & Yes & $124(32.9)$ \\
\hline \multirow[t]{2}{*}{ Axilla/Neck } & No & 338 (89.7) \\
\hline & Yes & 39 (10.3) \\
\hline \multirow[t]{2}{*}{ Other soft tissue } & No & $370(98.1)$ \\
\hline & Yes & $7(1.9)$ \\
\hline \multirow[t]{2}{*}{ Brain } & No & $264(70.0)$ \\
\hline & Yes & $113(30.0)$ \\
\hline
\end{tabular}

Abbreviation: LN, lymph node.

In the subgroup with squamous cell histology (n $=62), 18(29 \%)$ patients presented with abnormal serum CEA levels.

In multivariate logistic regression analysis (Table 4), non-squamous cell histology $(P=0.002)$, bone metastasis $(\mathrm{P}<0.001)$ and brain metastasis $(\mathrm{P}=0.005)$ showed strong correlations with abnormal serum CEA levels. Metastatic LN status $(\mathrm{P}=0.083)$ and lung to lung metastasis/lymphangitic spread $(\mathrm{P}=0.065)$ were also marginally influential factors for abnormal serum CEA levels.

We separately performed subgroup analysis in non-squamous cell histology $(\mathrm{n}=315)$ and also found that bone metastasis $(\mathrm{P}<0.001)$ and brain metastasis $(P=0.019)$ were independent factors associated with abnormal serum CEA in multivariate logistic regression analysis (results not shown in table).

\section{Were increased serum CEA levels correlated with whole-body metastatic potential?}

Table 5 shows the proportion of the cohort with abnormal serum CEA levels, according to the WBMS and LN-adjusted WBMS. The percentage of patients with abnormal serum CEA levels increased from $36.5 \%$ in the subgroup with WBMS of 1 to $100 \%$ in those with WBMS of 6 . Similarly, the percentage of
Table 3. Patient demographics and metastatic characteristics according to the serum CEA levels.

\begin{tabular}{|c|c|c|c|c|}
\hline \multicolumn{2}{|l|}{ Characteristics } & \multicolumn{2}{|c|}{ CEA levels } & $P$ value \\
\hline Gender & Male & $\begin{array}{l}\begin{array}{l}\text { Normal } \\
(<5 \mathrm{ng} / \mathrm{ml})\end{array} \\
111(47.0)\end{array}$ & $\begin{array}{l}\begin{array}{l}\text { Increased } \\
(\geq 5 \mathrm{ng} / \mathrm{ml})\end{array} \\
125(53.0)\end{array}$ & 0.013 \\
\hline & Female & $48(34.0)$ & $93(66.0)$ & \\
\hline \multirow[t]{2}{*}{ Age } & $<65$ & $72(40.9)$ & $104(59.1)$ & 0.641 \\
\hline & $\geq 65$ & $87(43.3)$ & $114(56.7)$ & \\
\hline \multirow[t]{2}{*}{ Histology } & Non-squamous & $115(36.5)$ & $200(63.5)$ & $<0.001$ \\
\hline & Squmaous & $44(71.0)$ & $18(29.0)$ & \\
\hline \multirow[t]{3}{*}{ Tumor differentiation } & WD-MD & $67(36.4)$ & $117(63.6)$ & 0.082 \\
\hline & $\mathrm{PD}$ & $58(46.8)$ & $66(53.2)$ & \\
\hline & Unknown & $34(49.3)$ & $35(50.7)$ & \\
\hline \multirow[t]{2}{*}{ Metastatic LN status } & $\mathrm{cN}-$ & $36(60.0)$ & $24(40.0)$ & 0.002 \\
\hline & $\mathrm{cN}+$ & $123(38.8)$ & $194(61.2)$ & \\
\hline \multirow{2}{*}{$\begin{array}{l}\text { Lung/Lymphangitic } \\
\text { spread }\end{array}$} & No & $78(51.3)$ & $74(48.7)$ & 0.003 \\
\hline & Yes & $81(36.0)$ & $144(64.0)$ & \\
\hline \multirow[t]{2}{*}{ Pleura/Effusions } & No & $82(41.6)$ & $115(58.4)$ & 0.821 \\
\hline & Yes & $77(42.8)$ & $103(57.2)$ & \\
\hline \multirow[t]{2}{*}{ Bone } & No & $96(58.5)$ & $68(41.5)$ & $<0.001$ \\
\hline & Yes & $63(29.6)$ & $150(70.4)$ & \\
\hline \multirow[t]{2}{*}{ Abdomen/Pelvis } & No & $107(42.3)$ & $146(57.7)$ & 0.947 \\
\hline & Yes & $52(41.9)$ & $72(58.1)$ & \\
\hline \multirow[t]{2}{*}{ Neck/Axilla } & No & $147(43.5)$ & $191(56.5)$ & 0.128 \\
\hline & Yes & $12(30.8)$ & $27(69.2)$ & \\
\hline \multirow[t]{2}{*}{ Brain } & No & $128(48.5)$ & $136(51.5)$ & $<0.001$ \\
\hline & Yes & 31 (27.4) & 82 (72.6) & \\
\hline \multirow[t]{2}{*}{ Other soft tissue } & No & 155 (41.9) & $215(58.1)$ & 0.418 \\
\hline & Yes & $4(57.1)$ & $3(42.9)$ & \\
\hline
\end{tabular}

patients with abnormal serum CEA levels increased from $24.3 \%$ in the subgroup with LN-adjusted WBMS of 1 to $100 \%$ in those with LN-adjusted WBMS of 7 .

Serum CEA levels according to LN-adjusted WBMS were analyzed to determine whether increased CEA levels correlated with whole-body metastatic potential. The median CEA value increased from $2.2 \mathrm{ng} / \mathrm{ml}$ in the subgroup with LN-adjusted WBMS of 1 to $366.7 \mathrm{ng} / \mathrm{ml}$ in those with LN-adjusted WBMS of 7 (P < 0.001, Table 6). Similarly, the low LN-adjusted WBMS group (score 1-2) exhibited significantly lower CEA levels compared with the high LN-adjusted WBMS group (score 3-7) (median 4.8 $\mathrm{ng} / \mathrm{ml}$ versus $21.0 \mathrm{ng} / \mathrm{ml}, \mathrm{P}<0.001$ ).

\section{Tumor and metastatic characteristics in cohorts with very high serum CEA levels}

We sought to identify whether very high serum CEA levels were associated with certain patient or metastatic characteristics. Very high serum CEA levels were defined as $\geq 100 \mathrm{ng} / \mathrm{ml}$. Regarding demographics, the proportion of the cohort with serum CEA level $\geq 100 \mathrm{ng} / \mathrm{ml}$ was $17 \%$ (64 patients). None of the patients showed squamous cell histology in the subgroup with very high serum CEA levels. In terms of metastatic characteristics, $c N+(P=0.007)$, bone 
metastasis $(\mathrm{P}<0.001)$ and brain metastasis $(\mathrm{P}=0.007)$ were significantly correlated with very high serum CEA levels (Table 7), and these findings were similar to the results categorized according to a serum CEA level of $5 \mathrm{ng} / \mathrm{ml}$. Abdomen/pelvis metastasis was additionally significantly associated with very high serum CEA levels ( $\mathrm{P}<0.001)$. Other soft tissue metastasis was also marginally associated with very high serum CEA levels $(\mathrm{P}=0.066)$.

Table 4. Logistic regression analysis for identifying correlating factors with increased serum CEA levels.

\begin{tabular}{|c|c|c|c|c|}
\hline \multirow[t]{2}{*}{ Factors } & & \multicolumn{3}{|c|}{ Univariate Multivariate } \\
\hline & & P value & $P$ value & OR $(95 \% \mathrm{CI})$ \\
\hline \multirow[t]{2}{*}{ Gender } & Male & 0.014 & 0.119 & 1 \\
\hline & Female & & & $1.458(0.908-2.342)$ \\
\hline \multirow[t]{2}{*}{ Age } & $<65$ & 0.641 & & \\
\hline & $\geq 65$ & & & \\
\hline \multirow[t]{2}{*}{ Histology } & Non-squamous & $<0.001$ & 0.002 & $2.682(1.415-5.08)$ \\
\hline & Squamous & & & 1 \\
\hline \multirow[t]{2}{*}{ Tumor differentiation } & WD-MD & 0.069 & & \\
\hline & PD & & & \\
\hline \multirow[t]{2}{*}{ Metastatic LN status } & $\mathrm{cN}-$ & 0.003 & 0.083 & 1 \\
\hline & $\mathrm{cN}+$ & & & $1.727(0.931-3.204)$ \\
\hline \multirow{2}{*}{$\begin{array}{l}\text { Lung/Lymphangitic } \\
\text { spread }\end{array}$} & No & 0.003 & 0.065 & 1 \\
\hline & Yes & & & $1.539(0.973-2.433)$ \\
\hline \multirow[t]{2}{*}{ Pleura/Effusions } & No & 0.821 & & \\
\hline & Yes & & & \\
\hline \multirow[t]{2}{*}{ Bone } & No & $<0.001$ & $<0.001$ & 1 \\
\hline & Yes & & & 2.549 (1.606-4.047) \\
\hline \multirow[t]{2}{*}{ Abdomen/Pelvis } & No & 0.947 & & \\
\hline & Yes & & & \\
\hline \multirow[t]{2}{*}{ Neck/Axilla } & No & 0.131 & & \\
\hline & Yes & & & \\
\hline \multirow[t]{2}{*}{ Brain } & No & $<0.001$ & 0.005 & 1 \\
\hline & Yes & & & 2.098 (1.251-3.52) \\
\hline \multirow[t]{2}{*}{ Other soft tissue } & No & 0.425 & & \\
\hline & Yes & & & \\
\hline
\end{tabular}

Table 5. Proportion of cohorts with increased serum CEA levels according to whole-body metastatic score and LN-adjusted whole-body metastatic score.

\begin{tabular}{lllll}
\hline Metastatic score & & \multicolumn{2}{c}{ CEA levels } & \multirow{2}{*}{ P value } \\
\cline { 2 - 4 } & & $\begin{array}{l}\text { Normal } \\
(<5 \mathrm{ng} / \mathrm{ml})\end{array}$ & $\begin{array}{l}\text { Increased } \\
(\geq 5 \mathrm{ng} / \mathrm{ml})\end{array}$ & \\
\hline Whole-body metastatic score & 1 & $66(63.5)$ & $38(36.5)$ & $<0.001$ \\
& 2 & $47(42.3)$ & $64(57.7)$ & \\
& 3 & $29(30.9)$ & $65(69.1)$ & \\
& 4 & $12(25.0)$ & $36(75.0)$ & \\
Whole-body metastatic score & 1 & $28(75.7)$ & $9(24.3)$ & $<0.001$ \\
(LN-adjusted) & 5 & $5(27.8)$ & $13(72.2)$ & \\
& 2 & $43(53.1)$ & $38(46.9)$ & \\
& 3 & $45(43.7)$ & $58(56.3)$ & \\
& 4 & $26(28.9)$ & $64(71.1)$ & \\
& 5 & $13(27.1)$ & $35(72.9)$ & \\
& 6 & $4(25.0)$ & $12(75.0)$ & \\
& 7 & $0(0)$ & $2(100.0)$ & \\
\hline
\end{tabular}

Abbreviation: LN, lymph node.
Table 6. Serum CEA levels according to LN-adjusted whole-body metastatic score.

\begin{tabular}{|c|c|c|c|}
\hline \multirow[t]{2}{*}{ Factor } & & \multirow{2}{*}{$\frac{\text { CEA levels }(\mathrm{ng} / \mathrm{ml} \text { ) }}{\text { Median (range) }}$} & \multirow[t]{2}{*}{$P$ value } \\
\hline & & & \\
\hline \multirow{9}{*}{$\begin{array}{l}\text { Whole-body metastatic score } \\
\text { (LN-adjusted) }\end{array}$} & 1 & $2.2(0.1-337.3)$ & $<0.001$ \\
\hline & 2 & $4.2(0.2-185.7)$ & \\
\hline & 3 & $6.9(0.1-2872.7)$ & \\
\hline & 4 & $16.5(0.1-1564.9)$ & \\
\hline & 5 & $31.4(0.5-837.0)$ & \\
\hline & 6 & $71.8(1.4-1000.0)$ & \\
\hline & 7 & 366.7 (62.8-670.5) & \\
\hline & Low score (1-2) & $4.8(0.1-2872.7)$ & $<0.001$ \\
\hline & High score (3-7) & $21.0(0.1-1564.9)$ & \\
\hline
\end{tabular}

Table 7. Patient demographics and metastatic characteristics according to the serum CEA levels (100 ng/ml).

\begin{tabular}{|c|c|c|c|c|}
\hline \multirow[t]{2}{*}{ Characteristics } & & \multicolumn{2}{|c|}{ CEA level } & \multirow[t]{2}{*}{ P value } \\
\hline & & $<100 \mathrm{ng} / \mathrm{ml}$ & $\geq 100 \mathrm{ng} / \mathrm{ml}$ & \\
\hline \multirow[t]{2}{*}{ Gender } & Male & $196(83.1)$ & $40(16.9)$ & 0.986 \\
\hline & Female & $117(83)$ & $24(17)$ & \\
\hline \multirow[t]{2}{*}{ Age } & $<65$ & $145(82.4)$ & $31(17.6)$ & 0.758 \\
\hline & $\geq 65$ & $168(83.6)$ & $33(16.4)$ & \\
\hline \multirow[t]{2}{*}{ Histology } & Non-squamous & $251(79.7)$ & $64(20.3)$ & $<0.001$ \\
\hline & Squmaous & $62(100)$ & $0(0)$ & \\
\hline \multirow[t]{3}{*}{ Tumor differentiation } & WD-MD & $151(82.1)$ & $33(17.9)$ & 0.234 \\
\hline & $\mathrm{PD}$ & $100(80.6)$ & $24(19.4)$ & \\
\hline & Unknown & $62(89.9)$ & $7(10.1)$ & \\
\hline \multirow[t]{2}{*}{ Metastatic LN status } & $\mathrm{cN}-$ & $57(95)$ & $3(5)$ & 0.007 \\
\hline & $\mathrm{cN}+$ & $256(80.8)$ & $61(19.2)$ & \\
\hline \multirow{2}{*}{$\begin{array}{l}\text { Lung/Lymphangitic } \\
\text { spread }\end{array}$} & No & $131(86.2)$ & $21(13.8)$ & 0.179 \\
\hline & Yes & $182(80.9)$ & $43(19.1)$ & \\
\hline \multirow[t]{2}{*}{ Pleura/Effusions } & No & $165(83.8)$ & $32(16.2)$ & 0.692 \\
\hline & Yes & $148(82.2)$ & $32(17.8)$ & \\
\hline \multirow[t]{2}{*}{ Bone } & No & $149(90.9)$ & $15(9.1)$ & $<0.001$ \\
\hline & Yes & $164(77)$ & $49(23)$ & \\
\hline \multirow[t]{2}{*}{ Abdomen/Pelvis } & No & $223(88.1)$ & $30(11.9)$ & $<0.001$ \\
\hline & Yes & $90(72.6)$ & $34(27.4)$ & \\
\hline \multirow[t]{2}{*}{ Neck/Axilla } & No & $284(84)$ & $54(16)$ & 0.128 \\
\hline & Yes & $29(74.4)$ & $10(25.6)$ & \\
\hline \multirow[t]{2}{*}{ Brain } & No & $229(86.4)$ & 36 (13.6) & 0.007 \\
\hline & Yes & $84(75)$ & $28(25)$ & \\
\hline \multirow[t]{2}{*}{ Other soft tissue } & No & 309 (83.5) & $61(16.5)$ & 0.066 \\
\hline & Yes & $4(57.1)$ & $3(42.9)$ & \\
\hline
\end{tabular}

Abbreviations: WD, well differentiated; $\mathrm{MD}$, moderate differentiated; PD, poorly differentiated; LN, lymph node.

\section{Discussion}

The present study showed that abnormal serum CEA levels could constitute a good surrogate marker for increased whole-body metastatic potential in stage IV NSCLC. In a previous study [13], we focused only on the identification of brain metastasis detection and its associations with pre-treatment serum CEA levels in stage IV NSCLC. This study was undertaken to reveal in greater detail the metastatic characteristics over the whole body in patients with abnormal serum CEA levels.

In our first series, we examined whether tumor marker values were correlated with whole-body tumor extent [13]. Tumor extent was categorized according to the whole-body metastatic regions and was 
scored based on the total metastatic area. Among five serum biomarkers, only CEA, cytokeratin 19 fragments (CYFRA 21-1) and cancer antigen 125 (CA 125) levels were significantly different between the low total metastatic group and the high total metastatic group. However, only serum CEA level was significantly associated with brain metastasis. In this study, the whole-body metastatic category was strengthened by the introduction of metastatic LN status evaluation. We hypothesized that metastatic LN status would also be a contributing factor to metastatic tumor aggressiveness and designated LN status-adjusted WBMS. As previously described, CEA was more commonly detected in tumors due to non-squamous cell carcinoma. In addition to brain metastasis, metastatic LNs, pulmonary and skeletal metastasis were also more frequently detected in cohorts with abnormal serum CEA levels, and brain and bone metastasis were independently correlated with abnormal serum CEA levels in the non-squamous cell subgroup, as well as in the entire cohort. The proportion of the cohort with abnormal serum CEA levels increased with the increase in WBMS and LN-adjusted WBMS (Table 5). The median serum CEA value also significantly increased as the LN-adjusted WBMS increased (Table 6). Importantly, abdomen/pelvis metastasis was significantly associated with very high serum CEA levels $(\geq 100 \mathrm{ng} / \mathrm{ml})$. Other soft tissue metastasis trended toward a significant correlation with very high serum CEA levels. Therefore, increased serum CEA levels might reliably reflect metastatic tendency to the whole body.

The possibility of increased metastatic potential in cohorts with abnormal serum CEA levels has been investigated [14, 15]. However, no clinical studies have examined whether whole-body metastatic potential could be dependently increased in advanced NSCLC patients with abnormal serum CEA levels. Considering the originating features of CEA (CEACAM5), cancer metastasis could be enhanced by increased serum CEA levels, with CEA functioning as an adhesion molecule and chemoattractant [16]. There has been much evidence that CEACAM5 can activate Kupffer cells and stimulate IL-1 $\beta$, IL- 6 and tumor necrosis factor- $\alpha$, thereby promoting adhesion of tumor cells to the endothelium [14-16]. Adhesion molecules that induce invasion can also facilitate the migratory process, resulting in the propagation of cancer metastasis [16]. On the basis of these molecular and experimental implications, the current study provided strong evidence of increased metastatic potential in abnormal serum CEA levels through clinical data.

Although the prognostic and predictive value of serum CEA has been rigorously explored, few studies have examined metastatic patterns or characteristics according to serum CEA levels. A strength of this study was its demonstration that abnormal serum CEA levels could constitute a strong indicative marker for increased whole-body metastatic potential in initially diagnosed stage IV NSCLC in this large study cohort. Moreover, metastatic LN status was evaluated along with the whole-body metastatic sites for the purpose of more precise evaluation of metastatic tumor status. Abnormal serum CEA levels were significantly associated with bone, brain, LN and pulmonary metastases, and very high serum CEA levels were also correlated with abdomen/pelvis and other soft tissue metastases. Our findings strongly support the possibility of the inhibition of metastatic processes in advanced lung cancer by antibodies that target CEA, as a previous preclinical study disclosed [16]. A multitude of recently developed CEA cancer vaccines are now in various stages of development and require further study to determine the ultimate roles of these vaccines in cancer treatments [7].

A limitation of this study was possible bias in the selection of the eligible study population who had available pre-treatment serum CEA levels. In fact, the percentage of samples with a histology characteristic of adenocarcinoma was higher (73.5\%) than reported in recent universal and nationwide epidemiologic data [17, 18]. Furthermore, metastatic status was evaluated by clinical and metabolic imaging and not by pathological examination. Whether increased serum CEA levels could enhance the specific metastatic affinity of particular sites remains unclear.

In conclusion, the present study showed that abnormal serum CEA levels were significantly correlated with increased whole-body metastatic potential in treatment-naïve stage IV NSCLC. Elevated serum CEA levels were more frequently found in patients with bone and pulmonary metastases and positive LNs, as well as with brain metastasis. Very high serum CEA levels $(\geq 100 \mathrm{ng} / \mathrm{ml})$ were additionally correlated with abdomen/pelvis metastasis. The study results suggested important epidemiologic aspects of metastatic distribution in advanced NSCLC. Further experimental studies investigating the secure role of serum CEA in the metastatic cascade are required in future studies.

\section{Competing Interests}

The authors have declared that no competing interest exists.

\section{References}

1. Jung KW, Won YJ, Kong HJ, Oh CM, Seo HG, Lee JS. Prediction of cancer incidence and mortality in Korea, 2013. Cancer Res Treat. 2013; 45: 15-21.

2. Jung KW, Won YJ, Kong HJ, Oh CM, Seo HG, Lee JS. Cancer statistics in Korea: incidence, mortality, survival and prevalence in 2010. Cancer Res Treat. 2013; 45: 1-14. 
3. Janssen-Heijnen ML, Coebergh JW. The changing epidemiology of lung cancer in Europe. Lung Cancer. 2003; 41: 245-58.

4. Travis WD, Lubin J, Ries L, Devesa S. United States lung carcinoma incidence trends: declining for most histologic types among males, increasing among females. Cancer. 1996; 77: 2464-70.

5. Choi CH, Kim WD, Lee SJ, Park WY. Clinical predictive factors of pathologic tumor response after preoperative chemoradiotherapy in rectal cancer. Radiat Oncol J. 2012; 30: 99-107.

6. Tan E, Gouvas N, Nicholls RJ, Ziprin P, Xynos E, Tekkis PP. Diagnostic precision of carcinoembryonic antigen in the detection of recurrence of colorectal cancer. Surg Oncol. 2009; 18: 15-24.

7. Gameiro SR, Jammeh ML, Hodge JW. Cancer vaccines targeting carcinoembryonic antigen: state-of-the-art and future promise. Expert Rev Vaccines. 2013; 12: 617-29.

8. Arrieta Rodriguez OG, Villarreal-Garza C, Martinez-Barrera L, et al. Usefulness of Serum Carcinoembryonic Antigen (CEA) in evaluating response to chemotherapy in patients with advanced non small-cell lung cancer: a prospective cohort study. BMC Cancer. 2013; 13: 254.

9. Cho S, Song IH, Yang HC, Kim K, Jheon S. Predictive factors for node metastasis in patients with clinical stage I non-small cell lung cancer. Ann Thorac Surg. 2013; 96: 239-45.

10. Hanagiri T, Sugaya M, Takenaka M, et al. Preoperative CYFRA 21-1 and CEA as prognostic factors in patients with stage I non-small cell lung cancer. Lung Cancer. 2011; 74: 112-7.

11. Lee S, Lee CY, Kim DJ, Hong DJ, Lee JG, Chung KY. Pathologic correlation of serum carcinoembryonic antigen and cytokeratin 19 fragment in resected nonsmall cell lung cancer. Korean J Thorac Cardiovasc Surg. 2013; 46: 192-6.

12. Horinouchi $\mathrm{H}$, Sekine I, Sumi M, et al. Brain metastases after definitive concurrent chemoradiotherapy in patients with stage III lung adenocarcinoma: carcinoembryonic antigen as a potential predictive factor. Cancer Sci. 2012; 103: 756-9.

13. Lee DS, Kim YS, Jung SL, et al. The relevance of serum carcinoembryonic antigen as an indicator of brain metastasis detection in advanced non-small cell lung cancer. Tumour Biol. 2012; 33: 1065-73.

14. Beauchemin N, Arabzadeh A. Carcinoembryonic antigen-related cell adhesion molecules (CEACAMs) in cancer progression and metastasis. Cancer Metastasis Rev. 2013.

15. Kuespert K, Pils S, Hauck CR. CEACAMs: their role in physiology and pathophysiology. Curr Opin Cell Biol. 2006; 18: 565-71.

16. Blumenthal RD, Hansen HJ, Goldenberg DM. Inhibition of adhesion, invasion, and metastasis by antibodies targeting CEACAM6 (NCA-90) and CEACAM5 (Carcinoembryonic Antigen). Cancer Res. 2005; 65: 8809-17.

17. Cetin K, Ettinger DS, Hei YJ, O'Malley CD. Survival by histologic subtype in stage IV nonsmall cell lung cancer based on data from the Surveillance, Epidemiology and End Results Program. Clin Epidemiol. 2011; 3: 139-48.

18. Jang TW, Kim YC, Jeong E. Female Lung Cancer: Re-Analysis of National Survey of Lung Cancer in Korea, 2005. Journal of Thoracic Oncology. 2011; 6: S1414-S5. 